\section{European defense industrial policy and the United Kingdom's defense industrial base}

\section{Keith Hartley}

$\mathrm{T}$

he United Kingdom's defense industrial base (UKDIB for short) cannot be viewed in isolation; it needs to be seen in the context of the European Union and its relationships with the United States. Both the EU and the U.S. protect their defense industries using Article 296 of the EU treaty and the Buy America Act (together with other protectionist policies). Compared with the United States, the European Union lacks a single European defense equipment market. ${ }^{1}$ In 2004, about 80 percent of EU defense equipment procurement (by value) was exempted from EU public procurement rules on national security grounds. ${ }^{2}$

Until recently, the U.K. defense equipment market was relatively open and subject to competition from foreign firms. This changed in late 2005 with the introduction of the United Kingdom's new Defense Industrial Strategy (DIS), which marked a shift from competition to protection and partnering for key parts of the UKDIB. Such a change occurred when the EU was formulating its defense industrial policy with efforts to create a European Defense Equipment Market (EDEM) and a European Defense Technology and Industrial Base (EDTIB). There are potential conflicts between Europe's aim of creating a more open EU defense market and the United Kingdom's desire to protect parts of its defense industrial base as reflected in its new Defense Industrial Strategy.

This article addresses two issues. First, it outlines developments in European defense industrial policy and addresses one topical element of EDEM policy, namely, the role of offsets in a single market. Second, it considers the role of the UKDIB within European defense industrial policy.

The defense industrial base in the European Union and in the United Kingdom

In 2003, employment in the world's arms industries was almost 7.5 million with the EU accounting for almost 10 percent of the total (see Table 1). Employment declined substantially following the end of the Cold War when the world's arms industries employed over 16 million people in 1990. Between 1990 and 2003, major employment reductions took place in Hungary, the Ukraine, Russia, and Germany. In contrast, employment reduction in the United States was relatively small, which might reflect its world power status, the influence of its military-industrial-political complex, and the defense sector's recovery due to the Afghanistan and Iraq conflicts. ${ }^{3}$ Defense industry employment is also concentrated in a few nations with the United States accounting for 36 percent of the 2003 world total compared with 19 percent of the
Table 1: Employment in the EU's arms industries (in thousands)

$\begin{array}{lrrlrr}\text { Regions/groups } & 1990 & 2003 & & 1990 & 2003 \\ \text { EU } & 1,330 & 724 & \text { USA } & 3,105 & 2,700 \\ \text { World total } & 16,241 & 7,479 & \text { China } & 3,996 & 2,100 \\ \text { Industrial states } & 11,291 & 4,710 & \text { Russia } & 2,516 & 780 \\ & & & & & \\ & & & & 1990 & 2003 \\ \text { EU nations } & 1990 & 2003 & & & \\ & & & & 15 & 15 \\ \text { France } & 382 & 240 & \text { Greece } & 100 & 10 \\ \text { United Kingdom } & 440 & 200 & \text { Estonia } & 10 & 10 \\ \text { Germany } & 240 & 80 & \text { Finland } & 20 & 10 \\ \text { Poland } & 180 & 50 & \text { The Netherlands } & 20 \\ \text { Italy } & 80 & 26 & \text { Slovakia } & 93 & 7 \\ \text { Bulgaria } & 100 & 25 & \text { Belgium } & 25 & 6 \\ \text { Sweden } & 30 & 25 & \text { Denmark } & 7 & 5 \\ \text { Spain } & 100 & 20 & \text { Portugal } & 10 & 5 \\ \text { Romania } & 90 & 18 & \text { Austria } & 5 & 3 \\ \text { Czech Republic } & 47 & 15 & \text { Hungary } & 33 & 2\end{array}$

Notes: Data for EU nations do not include EU members Cyprus, Ireland, Latvia, Lithuania, Luxembourg, Malta, and Slovenia. Apart from Denmark, all EU members are participating member states of the EDA. Nations are ranked by employment numbers in 2003 , the last published data from BICC. Sources: BICC (2002, 2005).

total in 1990. Within the EU, the top three nations of France, the U.K., and Germany accounted for 72 percent of total EU defense industry employment in 2003 (and an 80 percent share in 1990 but based on a smaller EU). Table 1 also shows the major size differences between the United States' defense industrial base (USDIB) and each of the top three EU nations; and the large number of European nations with relatively small defense industries. Such size differences between Europe and the United States and within the EU confirm the costs of national protection in Europe and the potential efficiency gains from a single EU Market for defense equipment. ${ }^{4}$

Since the end of the Cold War, a major re-structuring involving mergers and acquisitions in both the EU and the United States has led to larger defense firms and increased market concentration. European examples include BAE Systems (UK), EADS (Netherlands), Finmeccanica (Italy), Safran (including Snecma: France), and 
Thales (France). There has also been the emergence of military service companies reflecting military outsourcing, especially in the United Kingdom and the United States (some U.S. service companies have obtained contracts as a result of the Iraq war, e.g., KBR/Halliburton). ${ }^{5}$

Data on size, value added, and profitability of the top EU and U.K. defense firms is shown in Table 2. Problems arise because the data reflect both military and civil sales and are confined to the aerospace and defense group. Nonetheless, significant differences in the size of firms measured by sales, value added, and employment may be seen. By sales, EADS, BAE, and Thales are the largest European firms. There are also performance differences, reflected in value added and profitability. Within Table 2, Vosper Thorneycroft - a warship builder - has the lowest value added productivity and Dassault Aviation has the highest. Profitability varies from losses by Finmeccanica and BAE Systems to substantial profitability by Dassault, Cobham, and Megitt. Comparisons with the all-U.K. and all-European company averages show that aerospace and defense have higher value added productivity than the industry averages that represent the alternative use value of resources. However, for some companies these performance indicators are likely to reflect the economies of scale and learning from large-scale civil sales (e.g., EADS/Airbus; Rolls-Royce). Moreover, European and U.K. aerospace and defense are relatively less profitable than the industry averages raising questions about their continued presence in what appears to be a relatively less profitable industry.

\section{EU defense industrial policy}

Defense industrial policy involves procurement choices between the extremes of supporting a national defense industrial base or importing foreign arms (with or without offsets) or the intermediate solutions of international collaboration and licensed or co-production. Each option involves varying degrees of work-sharing and technology for the buying nation with corresponding alternative prices. ${ }^{6}$

Economic theory offers two key policy guidelines for EU defense industrial policy, namely, gains from trade and gains from scale and learning economies. Most EU defense markets are protected with preferential purchasing and support for national champions (e.g., Article 296 of the EU Treaty). Free trade among member states would lead to gains from specialization with trade based on comparative advantage. This requires abolition of tariff barriers, subsidies, and preferential purchasing by member states, thus allowing free entry and competition for national defense contracts. Firms from member states would be allowed to bid for defense contracts in each nation-state. In late 2005 , EU member states agreed a voluntary Code of Conduct for defense procurement to encourage competition in the EU defense equipment market where traditionally arms contracts were exempt from the normal EU internal market rules.?

Additional cost savings are available where arms industries are decreasing cost

Table 2: Major European defense companies

Company

European Union

$\overline{\text { EADS (Netherlands) }}$

Thales (France)

Finmeccanica (Italy)

SAFRAN (France)

Dassault (France)

SAAB (Sweden)

United Kingdom

BAE Systems

Rolls-Royce

Smiths

Cobham

QinetiQ

Vosper Thorneycroft

Meggitt

Ultra-Electronics

\section{Composites}

All U.K. areospace/defense

All U.K. companies

All EU aerospace/defense

All EU companies

(1) (2)

Columns: (1) sales (£m); (2) value-added (£m); (3) employment (numbers) (4) value-added per employee ( $£$ ' $000 \mathrm{~s})$; (5) profits on sales $(\%)$.

Notes: (i) Defense is based on the aerospace and defense group; (ii) companies are ranked by value added; (iii) all company composites for Europe are based on the top-700 European companies, with sales and value added as averages for the 700 companies and includes the top U.K. firms; for U.K. companies,

averages are based on the top-800 companies; (iv) DTI does not publish similar data for the United States.

Source: DTI (2006)

industries (e.g., aerospace). Greater output reduces unit R\&D costs and leads to economies of scale, learning, and scope: such economies are not achieved in small- 
scale EU national defense markets but are available in a single arms market embracing all member states of a military alliance. Estimates suggest that competition effects might lead to unit-cost savings of 10 percent to 25 percent with scale and learning economies probably contributing a 15 percent to 25 percent reduction in unit costs. $^{8}$

Policies to introduce an efficient defense industrial policy will, like all policies, involve gainers and losers. Potential gainers include those industries and firms which are privately owned and have already been exposed to competition and competitively-determined fixed price contracts. Possible losers will be state-owned firms which operated in protected markets receiving subsidies and cost-plus contracts. Changes to establish a more efficient industrial policy will involve adjustment costs and will take time. There will be some unemployment and underemployment of resources, reflected in job losses, plant closures, exits from the industry, and local unemployment. Potential losers will oppose change and will lobby for "fair and managed" competition with work allocated on a juste retour basis and protection for EU defense industries (e.g., Fortress Europe). With such pressures from producer groups, the ideal of an efficient defense industrial policy might soon be transformed into cartels, collusive tendering, a lack of rivalry, and inefficient EU defense industries.

Within Europe, collaboration has been the most distinctive of its defense industrial policies, especially in aerospace systems (e.g., 3-nation Tornado; 4-nation Eurofighter Typhoon). ${ }^{9}$ In theory, ideal or perfect international collaboration leads to savings in development and unit production costs. Actual collaboration involves departures from the ideal case with work-sharing based on political, equity, and bargaining criteria (juste retour) rather than efficiency criteria, resulting in inefficiencies in both development and production and longer development times. Collaboration fails to exploit gains from trade; but it does achieve economies of scale and learning although these are not fully realized due to each nation's desire for a final assembly line.

A U.K. study provided evidence on the inefficiencies of collaboration. It estimated that total development costs on collaborative projects were some 140 percent to almost 200 percent higher than comparable national programs, depending on the number of partner nations; but the U.K.'s cost share on collaborative programs was about one-third of total development costs. On production, it was found that collaboration achieved scale and learning economies in the region of half of those on national projects with collaboration causing an average of 11 months delay. ${ }^{10}$ Cost overruns and delays on collaborative programs reflect the transaction costs of international contracting, including the management of collaborative programs, the cooperative industrial arrangements, and changed order quantities as well as budget constraints and delayed approvals by national partners. ${ }^{11}$ Current European defense industrial policy is focused on creating a single market for defense equipment and a European defense industrial base based on initiatives pursued by both the European Commission and the European Defense Agency (EDA).
A European defense market: market openness and offsets

The European Defense Agency has introduced initiatives to create a single European market for defense equipment. These include an inter-governmental agreement for a voluntary Code of Conduct aimed at opening defense markets of member states and promoting competition, including transparency and accountability procedures. With this new system, EDA will publish procurement opportunities and contract details through an electronic bulletin board. Under the Code of Conduct, member states are committed to purchasing defense equipment from each other on the basis of best value, instead of automatically contracting with a national supplier. The Code covers defense equipment purchases that governments choose to exempt from EU public procurement rules under Article 296 and that do not usually involve any cross-border competition. Member states requiring an exemption from the Code of Conduct must provide an explanation to the agency. However, the Code of Conduct is not legally binding so is unlikely to achieve much impact. There are also concerns that efforts to create a common European defense equipment market will be affected by state support, subsidies, state ownership, security of supply, intra-community trade, export policies, and different military requirements. Furthermore, EDA is assessing the impact of offsets on competition and defense industry restructuring. There is a concern that offsets distort competition, promote inefficiency in defense procurement, affect transparency in procurement, and might impair efforts to establish a European Defense Technology and Industrial Base. Questions arise as to what is known, what is not known, and what it is necessary to know to formulate a sensible policy on offsets in the European defense equipment market. ${ }^{12}$

\section{Estimating offsets}

Import data in Table 3 can be used to provide an upper bound estimate of the annua value of offsets for participating member states of the European Defense Agency in 2005. This upper bound estimate of $€ 4.2$ billion is based on the limiting assumption that all imports are associated with an offset - an unrealistic assumption but one which provides a starting point for estimating the value of offsets for EDA member states. On the basis of the import data, we expect the annual value of offsets for all members to be less than $€ 4.24$ billion in 2005 . These data refer to annual values only: typically, offset data are shown for the total value of the offset, which usually involves transactions over a number of years (e.g., see data in the annual SIPRI yearbooks).

The upper bound estimate can be modified further by considering some countries' offsets as a share of total defense equipment foreign trade (exports or imports). For example, for U.S. defense equipment exports to the U.K. over the period 1993-2005, offsets accounted for 84 percent of the total value of such exports. Similarly, for U.S. defense exports to the top- 9 EDA member states over this same period, offsets accounted for some 79 percent of the total value of such U.S. exports. ${ }^{13}$ On this basis, 
Table 3: Procurement, imports, and employment

$\begin{array}{lrrrr}\text { Country } & \text { (1) } & \text { (2) } & \text { (3) } & (4) \\ \text { Austria } & & & & \\ \text { Belgium } & 184 & 26 & 14 & 3 \\ \text { Cyprus } & 223 & 0 & 0 & 6 \\ \text { Czech Republic } & 213 & 772 & (362) & 15 \\ \text { Estonia } & 20 & 12 & 60 & 10 \\ \text { Finland } & 539 & 94 & 17 & 10 \\ \text { France } & 5,618 & 4 & <1 & 240 \\ \text { Germany } & 3,445 & 265 & 8 & 80 \\ \text { Greece } & 1,400 & 1,366 & 98 & 15 \\ \text { Hungary } & 106 & 15 & 14 & 2 \\ \text { Ireland } & 94 & 5 & 5 & 0 \\ \text { Italy } & 2,119 & 275 & 13 & 26 \\ \text { Latvia } & 14 & 9 & 64 & 0 \\ \text { Lithuania } & 37 & 11 & 30 & 0 \\ \text { Luxembourg } & 24 & 0 & 0 & 0 \\ \text { Malta } & 9 & 22 & (244) & 0 \\ \text { The Netherlands } & 1,215 & 158 & 13 & 10 \\ \text { Poland } & 633 & 118 & 19 & 50 \\ \text { Portugal } & 223 & 498 & (223) & 5 \\ \text { Slovakia } & 95 & 0 & 0 & 7 \\ \text { Slovenia } & 39 & 3 & 8 & 0 \\ \text { Spain } & 2,166 & 345 & 16 & 20 \\ \text { Sweden } & 1,217 & 128 & 11 & 25 \\ \text { U.K. } & 6,699 & 115 & 2 & 200 \\ \text { Total } & 26,380 & 4,241 & 16 & 724\end{array}$

Columns: (1) defense equipment procurement (€m, 2005); (2) arms imports (€m, 2005); (3) import share of equipment procurement (\%); (4) defense industry employment ('000s; 2003).

Notes: (i) for imports, $€$ 's estimated at exchange rate of $€=\$ 1.2155$ (June 2005); also, SIPRI data originally in 1990 US $\$$ prices and converted to 2005 prices using USA CPI; (ii) figures are rounded; (iii) figures in brackets show where imports exceed procurement spending suggesting data discrepancies either with import or procurement data; imports are for major conventional weapons only (SIPRI data); (iv) employment data from BICC: the series was discontinued after 2005 so the latest data are for 2003; where BICC did not provide any data, the country entry was recorded as zero $(0)$. offsets for EDA members might account for between 79 percent and 84 percent of total arms imports, equivalent to between $€ 3.4$ to $€ 3.6$ billion in 2005 .

The import data also show the magnitude of foreign market opportunities among EDA members, namely, a foreign trade value of $€ 4.24$ billion in 2005 . However, import figures for one year are unlikely to indicate longer-term trends. For the period 2001-2005, the aggregate value of imports of major conventional weapons for EDA members totaled some $€ 21.3$ billion (another indicator of the maximum upper bound figure of offsets over the period 2001-2005). Interestingly, the aggregate value figure results in an annual average of imports for the members states of $€ 4.3$ billion (similar to the 2005 data).

Estimates were made of rank correlations between defense procurement in 2005 against imports in 2005 and against aggregate imports over the period 2001-2005. In each case, significant and positive coefficients were estimated with a coefficient of $\mathrm{r}=0.585$ for defense procurement in 2005 against imports in 2005 (significant at the 1 percent level, $t=4.2$ ) and a rank correlation of $r=0.84$ for defense procurement in 2005 against aggregate imports over the period 2001-2005 (highly significant, $\mathrm{t}=$ 13.7).

The European defense equipment market: market openness

Table 3 also provides estimates of import penetration of defense equipment markets, data which are useful in assessing the openness of participating EDA member states' defense markets and the contribution toward the development of a European defense equipment market. There are substantial variations in market openness ranging from almost 100 percent for Greece to under 1 percent for France. The average market openness is 16 percent. (An alternative estimate is 10 percent for military markets compared with 25 percent for civilian orders. ${ }^{14}$ ) Typically, the nations with a relatively large defense industrial base (employment of 20,000 or more) were the ones with relatively low degrees of import penetration, suggesting substantial market protection. France, Germany, Italy, Sweden, and the U.K. each had import penetration rates below the EDA member states' average (Poland was above and Spain was at the average). A rank correlation based on the top-7 defense industries found a significant and positive correlation between defense industry employment and the degree of protection (measured by import shares; $r=0.75$, significant at the 5 percent level), but when the sample was extended to include other nations, the rank correlation was not significant $(\mathrm{r}=0.0061) .{ }^{15}$

United States data on European and United Kingdom offsets

The United States Congress publishes regular reports on offsets in defense trade. These reports provide data on offset percentages and country policies for EU nations based on U.S. defense exports. Table 4 shows the average percentage offsets for the 
period 1993 to 2005 while the country percentage reflects the current offset percentage required by each national government. Most countries set a single target percentage offset value; but a few nations vary the percentage depending on the significance of the individual offset to the local economy. Table 4 and other evidence from U.S. Congressional reports provides some generalizations about offsets from the United States.

- For EDA nations, offsets achieved varied substantially from 28 percent for Portugal to 174 percent for Austria. Often, the achieved offset was substantially below the country target percentage. Even nations with a large defense industrial base did not achieve their 100 percent target (i.e., France, U.K.) while countries with a relatively small defense industry often achieved a relatively high percentage offset (i.e., Austria, Greece, the Netherlands).

- Regional offset percentages are greater in Europe compared with all other regions of the world.

- There is some evidence of an upward trend in offset requirements for U.S. defense exports. For the period 1993-1998, the offset percentage totaled 55 percent of the value of U.S. defense exports and the percentage rose to 87 percent over the period 1999-2005. Over the whole period 1993 to 2005, the offset percentage averaged 71 percent with a peak of 125 percent in 2003, falling to 65 percent in 2005 .

- Direct defense offsets accounted for about 40 percent of all offsets. Subcontracts accounted for almost 60 percent of the value of all direct offsets, with most of these being aerospace-related.

- Indirect offsets accounted for some 60 percent of all offsets. ${ }^{16}$ Typically, purchases, usually aerospace-related, accounted for over 60 percent of the value of indirect offsets. However, the data on indirect offsets are dubious. They are defined as defense goods and services unrelated to the defense export, suggesting that they are indirect defense offsets. However, the text in the U.S. Congressional reports implies that they include indirect civil sales.

- Technology transfer, defined broadly, accounted for some 17 percent of the value of all offsets over the period 1993-2005. During this period, about 42 percent of the value of technology transfer was classified as direct offsets and 56 percent as indirect offset. ${ }^{17} \mathrm{With}$ direct offsets, for most U.S. prime contractors the technology transferred is not leading edge. ${ }^{18}$

- As regards country distribution, European countries accounted for the majority of offset activity with 65 percent of the value of offsets, but under 50 percent (47 percent) of the value of U.S. defense exports. Over the period 1993-2005, U.S. firms reported entering into 286 offset agreements with European countries to a total value of some $\$ 37$ billion and an average value of $\$ 128.5$ million per agreement and an average duration of almost 85 months. ${ }^{19}$

- Over the period 1993-2005 countries with developed, technically advanced economies have demanded higher levels of offset than other nations. However, countries outside Europe are now demanding higher offset percentages. Also, foreign defense purchases are being driven by the competitiveness of the offset package offered by U.S. industry rather than by the quality and price of the defense system acquired. ${ }^{20}$

- Offsets are not free. Estimates show that they increase the price of defense equipment by as much as 15 percent to 30 percent. $^{21}$

- Offsets can lead to U.S. prime contractors discovering innovative, re $1 \mathrm{i}$ a b le, a n c o s t - effective subcontractors that they would not otherwise have found On this basis, some o f f s e t s a r e trade-creating.

Offsets and the European defense equipment market

Critics regard offsets as a source of inefficiency in defense procurement and a barrier to the creation of a

European defense equipment market through their introduction of non-price factors into procurement choices and value for money criteria. Further, they claim that

offsets, if badly targeted, can conflict with the aims of creating a European defense

Table 4: Data on U.S. offsets, 1993-2005

Country groups Percentage Country Europe (EDA) offsets (\%) percentage (\%)

Austria $\quad 174 \quad 200$

Belgium $\quad 80 \quad$ Case-by-case

Czech Republic n/a $\quad 100$

Finland $\quad 100 \quad 100$

France $\quad 85 \quad 100$

Germany $\quad 100 \quad$ up to 100

Greece $\quad 113 \quad 80$ to 300

Hungary n/a n/a

Italy $94 \quad \min .70$

The Netherlands 119 up to 150

Poland n/a 100

Portugal $28 \quad 100$

Spain $\quad 89$ up to 100

Sweden $\quad 104 \quad 100$

U.K. $\quad 84 \quad 100$

Offset percentages:

- Europe regional total: 99 (EDA median: 99)

- North and South America regional total: 97

- Middle East and Africa regional total: 43

- Asia regional total: 39

- U.S. data, all offsets, 1993-1998: 55

- U.S. data, all offsets, 1999-2005: 87

Notes: $\mathrm{n} / \mathrm{a}=$ not available; data are rounded; Europe group shows EDA participating member states (pMS) for which data are provided; not all pMS states are reported and some non-pMS states are reported. Europe regional total refers to all European countries reported by the U.S. data. Source: USDC (2007, Table 2-5, pp. 2-13). 
industrial base and that all offsets are difficult to administer and to deliver in practice. Such claims need to be evaluated.

Offsets might lead to the discovery of lower-cost suppliers and allow entry into highly-protected defense markets. Also, the criteria for the most economically advantageous offer in any procurement competition allows consideration of non-price factors. The point about badly targeted offsets and the European defense industrial base suggests that there are correctly targeted offsets that might contribute to creating such a defense industrial base. Finally, claims about administration and delivery of offsets are empirical issues requiring supporting data on transaction costs.

There are various options for an EU policy on offsets. First, there could be a ban on all offsets for defense trade between member states involving EU firms. Such a ban would be strongly opposed by various member states who support offsets and would place EU firms at a competitive disadvantage with U.S. defense firms in European markets. Second, there could be harmonization of offset policies where the harmonization might involve minimum thresholds or a maximum offset percentage (e.g., a cap of 100 percent) or the specification of the weight to be placed on offsets in procurement choices and the introduction of a common external offsets policy (similar to the common external tariff). Third, efforts might be made to identify "desirable" and "undesirable" offsets in relation to their impact on the European defense industrial base. The European Defense Agency could also act to break the offsets trap where nations are competing to maximize offsets (cf., subsidy trap). Or, policy might focus initially on transparency requiring that member states specify their offset requirements in all invitations to tender with a possible further requirement that offsets be non-discriminatory between national and other firms. In fact, current EDA policy on offsets aims "to create the market conditions and the European DTIB structure, in which the practice may no longer be needed - and meanwhile to consider how adverse impact on competition and the DTIB might be mitigated." ${ }^{22}$ However, there are more serious issues concerning the creation of a European defense equipment market. Typically, member states rely on the national security exception in Article 296 to make most of their defense purchases on a national basis. ${ }^{23}$ Efforts to open up national defense markets of member states continue to offer the greatest opportunities for substantial efficiency improvements. There are also wider issues about the European defense industrial base.

The European technological and defense industrial base

The European Defense Agency has announced a policy on the future European Defense Technological and Industrial Base (EDTIB). This is needed to supply equipment to the EU's armed forces, including world-leading technology equipment and to allow independent operations. A EDTIB is also seen as a valuable economic asset as a major source of jobs, exports, and technological advance. However, the agency recognizes the need for fundamental change in policy toward a EDTIB. A truly European defense technological and industrial base is no longer economically sustainable on a national basis with separate national research and development and procurement programs. For example, Europe has four main battle tank programs compared with one in the United States; twenty-three national programs for armored fighting vehicles; and eleven frigate programs compared with one in the United States. $^{24}$

The EDA view of the EDTIB is one which is “... more integrated, less duplicative and more interdependent - increased specialisation at all levels of the supply chain, must take over from all (or at least too many) trying to do everything. Centres of excellence should emerge from a market-driven process, moderated by policy considerations including the requirement to achieve an appropriate regiona distribution." 25 Policy also refers to identifying, preserving, and developing "key" European technologies and industrial capacities as well as ensuring security of supply for all member states in a "truly European DTIB." "26

Attractive though a European DTIB policy appears, there is a need for much more clarification. Concepts such as "key" technologies and industrial capabilities are vague: what are these capabilities, why are they key, and are they to be retained regardless of costs? Potential conflicts are likely between the aims of an EDEM and an EDTIB: a genuinely competitive and open defense market is unlikely to support an "appropriate regional distribution" of the "key" technologies and industrial capabilities. Nor are there any indications of the optimum size of EDTIB and of its constituent firms. For example, which nations have a comparative advantage in which areas of air, land, and sea systems as well as in R\&D, production, and subcontracting? Will the EU market only support one monopoly supplier for some types of defense equipment (e.g., aircraft carriers; nuclear-powered submarines; space systems)? Further potential problems arise between the desire for a EDTIB and nationa preferences for retaining key defense industrial capabilities (e.g., as in the U.K.'s Defense Industrial Strategy)

The U.S. defense industry which supplies a large single American market might provide a model for an EDTIB. The U.S. Department of Defense submits an Annual Industrial Capabilities Report to Congress. ${ }^{27}$ This outlines ideal industry characteristics such as a reliable and cost-effective defense industrial base, including an "adequate" number of competitive suppliers in key and emerging technology areas and opportunities for new entry by innovative suppliers. The reports contain a detailed analysis and assessment of industrial and technological capabilities embracing primes, subcontractors, and critical sole-source suppliers (e.g., missile solid rocket motors). For example, in the aircraft industrial sector, the report questions Boeing's future in the combat and transport aircraft sectors and raises doubts about the future availability of titanium for the aerospace industrial base. It also suggests that suppliers not associated with the F-35 program are at risk.

Increased industrial concentration is highlighted. In ground vehicles, it notes that during the $1990 \mathrm{~s}$, the number of prime contractors reduced from eleven to two 
(General Dynamics Land Systems and BAE Ground Systems Division). Similarly, in missiles, the number of primes fell from over twelve to six (dominated by Raytheon and Lockheed Martin) and bottlenecks in the supplier base remain. In shipbuilding, there are six major U.S. shipyards shared equally between Northrop Grumman and General Dynamics. Significant excess capacity exists, leading to higher overhead costs. Concern was also expressed that the United States' unique submarine design industrial base could downsize significantly, as happened in the U.K. where the eventual result was large cost overruns and schedule delays.

A similar annual report on European defense industrial capabilities would provide EDA and policymakers with the necessary information for making informed choices on the EDTIB. Significantly, the U.K. recently published a similar comprehensive review of its defense industrial base in the form of the Defense Industrial Strategy which has implications for the development of European defense industrial policy.

The United Kingdom's defense industrial base and its defense industrial strategy

The U.K. Ministry of Defense (MoD) is a major buyer of defense equipment and services, spending some $£ 16$ billion on R\&D, equipment, and support in 2005.This buying power forms a major component of the demand side of the U.K. defense equipment market and can be used to determine the size, structure, behavior, performance, and ownership of the UKDIB. Exports are a further component of market demand, valued at some $£ 7.1$ billion in 2005 . U.K. defense industrial policy is based on the 2005 Defense Industrial Strategy (DIS), ${ }^{28}$ and the associated Defense Technology Strategy (DTS). ${ }^{29}$ The DIS is the most comprehensive statement of U.K. defense industrial policy ever published by a U.K. government. It provides data on the UKDIB; it provides guiding principles for the Strategy; it outlines the problems facing the defense industries; and it identifies the key industrial capabilities which will be retained in the United Kingdom.

The DIS contains data on the UKDIB, and some of the main features are shown in Table 5. The Table shows annual MoD spending and its allocation between R\&D, equipment, and support services. Support services accounted for over 50 percent of MoD spending and the DIS forecasts a significant growth of this business. The DIS also confirms the relative openness of the U.K. defense market, where over 30 percent of MoD industrial spending was with foreign-owned companies, collaborative programs, and imports (with imports accounting for about 14 percent of equipment spending in 2005). Labor productivity in the UKDIB is higher than the average for U.K. industry suggesting that the defense industries are more productive than the average alternative use of resources (i.e., the UKDIB makes a net contribution to national output). However, employment in the UKDIB has declined substantially from 740,000 employees in 1980/81 to 550,000 at the end of the Cold W ar and the 310,000 personnel in 2005. The DIS forecasts further employment reductions and substantial excess capacity in U.K. production facilities. Indeed, the DIS reflects the need for the

Table 5: The United Kingdom defense industrial base, 2005

Total MoD spending in $£$ billions

Support services

Equipment

Research and technology

Total

9.0

2.3

Country-ownership allocation of MoD spending (in \%)

U.K.-owned and based companies

Foreign-owned U.K.-based companies

Collaborative projects

Imports

U.K. defense exports (deliveries) in $£$ billions

14.0

13.0

5.0

7.1

Productivity (value added per employee in $£$ '000s)

U.K. defense industry

All U.K. industries

Total employment in U.K. defense industries (in '000s) - including employment on defense exports

Major firms paid over $£ 250$ million by MoD in 2005/06: BAE Systems, Finmeccanica, General Dynamics, QinetiQ, Babcock, EADS, EDS,

Halliburton, Lockheed Martin, Raytheon, Rolls-Royce, Serco, and Thales.

Sources: DIS (2005); DASA (2006).

UKDIB to adjust to a future of major gaps in development and production work, raising questions as to which defense industrial capabilities the United Kingdom wishes to retain, how such capabilities will be retained, and at what cost.

The DIS specifies that the sectors to be retained in the U.K. include submarines, core workload warship building, small arms ammunition, and cryptography together with support capabilities for manned fixed wing aircraft, helicopters, and armored fighting vehicles. Elsewhere, the United Kingdom retains the right to buy from overseas for large aircraft, trainer aircraft, helicopters, missiles, torpedoes, and some warships. Future business in the defense industry is expected to be dominated by support and upgrading of platforms. It is also recognized that as industrial rationalization continues, sustaining competition for domestic requirements will be 
increasingly difficult. Once the current generation of major projects enters service, there is forecast to be substantial excess capacity. For example, the projected end of any new design manned fast jet aircraft threatens the U.K.'s existing design, development, and manufacturing capabilities (e.g., BAE plants at Brough, Woodford, Warton, and Samlesbury).

The DIS plans to retain key parts of the UKDIB by offering protected and guaranteed markets to preferred suppliers through long-term partnering agreements. These agreements will be with domestic monopolies and will replace competition as a means of delivering best long-term value for money (e.g., where competition is not possible or inappropriate). Inevitably, concerns arise about the economic impact of the shift from competition to monopoly and partnering. Standard economic theory predicts that partnering will lead to monopoly behavior reflected in higher prices, inefficiency, monopoly profits, and a poor performance on innovation. There are also potential conflicts between the DIS partnering model based on protected and guaranteed U.K. defense markets and the EU's efforts to create a European defense equipment market based on open and competitive markets. Interestingly, before the DIS, U.K. procurement policy was based on open and competitive markets.

The DIS raises further issues of concern. There will be more emphasis on non-competitive contracts with all their problems (e.g., estimating and agreeing costs, profits, and prices). The role of wider factors in procurement choices represents a further unknown in the DIS (e.g., what are these wider factors; are they based on market failures; do they allow Ministers opportunities for distorting procurement choices?). Also, supporting key U.K. defense industries involves a willingness to pay for such capabilities, but various parts of the DIS refer to the need to avoid paying a U.K. premium. Finally, the dominant position of BAE Systems with its domestic monopolies in air, land, and sea systems needs to addressed. There are concerns about a cosy relationship between the contractor and MoD which might be controlled by treating BAE as a regulated firm or subjecting it to periodic efficiency audits by the U.K. Competition Commission. ${ }^{30}$

\section{Conclusion}

European, U.K., and U.S. defense firms are faced with change. Defense firms have a long history of change and uncertainty. New technology has resulted in revolutions in arms and armed forces. Examples include the emergence in the twentieth century of manned aircraft, missiles, and nuclear weapons. Continued technical change and the emergence of new threats (e.g., international terrorism) means that the future defense firm will be different from today's defense firm. Not all existing arms firms will survive and adjust to new technologies. Future aerospace firms will shift from manned combat aircraft to unmanned combat air vehicles, missiles and space systems, and the electronics industry is likely to become more important providing the next generation of new entrants, systems integrators, and prime contractors. New forms of industrial organization will also emerge characterized by buying rather than making, using international supply chains in a global economy leading to more international arms firms. ${ }^{31}$

Costly, defense specific equipment will create further challenges for European and U.K. governments and the defense industrial base. Examples include aircraft carriers, main battle tanks, manned strategic bomber aircraft, and nuclear-powered submarines. Increasingly, these are purchased in small numbers with long gaps in development between new generations of equipment. Where such systems require highly specific human and physical capital (e.g., nuclear-powered submarines), ${ }^{32}$ there will be problems and costs in maintaining such assets during gaps in development. The absence of competition for these weapons means that their prime contractors will have to be treated as regulated firms requiring procurement agencies to review their regulatory policies for non-competitive contracts (cf., regulation of natural monopolies). Continued industry re-structuring among both prime contractors and suppliers means that national markets will be dominated by larger firms and domestic monopolies. Competition remains an efficient policing mechanism, but it will require a government's willingness to open up its national defense market to allow foreign firms to bid for arms contracts with possible adverse impacts on the EDTIB and domestic defense industries.

For the EU, there are likely to be conflicts between its efforts to open up national defense markets and the desire to create and maintain an EDTIB and for nations to retain a domestic defense industry (e.g., the U.K.'s DIS). The notion of an EDTIB remains vague (e.g., compare the U.S. model). Even if the defense industrial base can be defined, choices will be needed about its geographical distribution (e.g., the desire for fair shares), the likely monopoly of some costly and highly specialized industrial capabilities (e.g., aircraft carriers; missiles; space systems; nuclear-powered submarines), and the possibility of duopoly-oligopoly in other sectors of the EDTIB (e.g., helicopters; manned combat aircraft; transport aircraft; main battle tanks).

The United Kingdom is already making such choices through its Defense Industrial Strategy, which has identified key capabilities that the U.K. plans to retain through guaranteed markets and partnering agreements with preferred suppliers. The development of an EDTIB might require the U.K. to make further difficult choices through being more selective about which defense industrial capabilities are to be retained in the U.K. For example, can the U.K. (and France) afford to retain a costly submarine industrial base supplying one product to one customer in small numbers? It might be more cost-effective to focus on the U.K. aerospace industry as a successful defense industrial sector. Nor can the U.K.-U.S. relationship be ignored in formulating a European defense industrial policy. The U.K's major defense firms have substantial business investments in the U.S. defense industry (e.g., BAE, Roll-Royce) while American and European defense firms own substantial parts of the UKDIB (e.g., Smiths Aerospace owned by GE; AgustaW estland owned by Finmeccanica). For U.K firms, the U.S. defense market is a large and relatively profitable market. The creation 
of a European defense equipment market would provide a similar large and potentially profitable market for U.K. and European firms.

\section{Notes}

Keith Hartley is Professor of Economics and directs the Center for Defense Economics, both at the University of York, England. He may be reached at kh2@york.ac.uk.

\section{DIS (2005, p. 26).}

2. That is, using Article 296. See DIS (2005, p. 29).

3. In fact, employment in the U.S. defense industrial base declined by some 35 percent from $1989 / 90$ to 1998 , after which it increased.

4. Dunne and Surry (2006).

5. See Sköns and Surry (2005)

6. Hartley (1995).

7. EU (2005).

8. Hartley (2006).

9. The Joint Strike Fighter, or JSF, is an international cooperative program consisting of the United States and eight foreign partners (U.K., Italy, Netherlands, Turkey, Denmark, Norway, Canada, and Australia). The partners have made various financial contributions to the development phase in return for an involvement in the program. However, the aircraft is a U.S. design with Lockheed Martin as prime contractor. Problems have arisen over the work allocated to the foreign partners, especially access to advanced technology (technology transfer).

\section{NAO (2001)}

11. NAO (2001).

12. Brauer and Dunne (2004).

13. USDC (2007)

\section{Kuechle (2006, p. 8).}

15. For this larger sample, the limited data set was based on removing outliers (data in brackets in Table 4) and omitting nations with apparently zero defense employment but with imports less than domestic procurement, suggesting that these nations might have had defense industry employment which was not shown by the BICC data. The result was a sample of $\mathrm{n}=15$ nations.

16. USDC (2007, Table 2-2, pp. 2-5).

17. The balance was unspecified; USDC (2007, pp. 2-7).

18. USDC (2007, Interagency Team, pp. 4-16).

19. USDC (2007,pp. 4-5)

20. USDC (2007, pp. 4-9)

21. USDC (2007, p. vi)

22. EDA (2007, p. 5).

23. EDA (2007, p. 4).

24. Kuechle (2006, p. 26).

25. EDA (2007, p. 2).

26. EDA (2007, p. 3)

27. DoD (2007)

28. DIS (2005)

29. DTS (2006)

30. Hartley (2007).

31. Hartley and Sandler (2003).

32. Ireland (2007). 


\section{References}

Brauer, J. and J.P. Dunne, eds. 2004. Arms Trade and Economic Development: Theory, Policy and Cases in Arms Trade Offsets. London: Routledge.

[BICC] Bonn International Center for Conversion. 2002, 2005. Conversion Survey. Baden-Baden, Germany: Nomos Verlagsgesellschaft.

[DIS] Ministrry of Defense. 2005. Defence Industrial Strategy. Ministry of Defence. London: The Stationery Office. Cmnd 6697 (December).

[DoD] Department of Defense. 2007. Annual Industrial Capabilities Report to Congress. Washington, DC: Department of Defense. (February).

[DTI] Department of Trade and Industry. 2006. The Value Added Scoreboard, 2006, Company Data. Vol. 2. London: Department of Trade and Industry.

[DTS] Ministry of Defense. 2006. Defence Technology Strategy. London: The Stationery Office.

Dunne, J.P. and Surrey, E. 2006. “Arms production,” in SIPRI Yearbook 2006. Oxford: Oxford University Press.

[EDA] European Defense Agency. 2007. A Strategy for the European Defense Technological and Industrial Base. Brussels: European Defense Agency.

[EU] European Defense Agency. 2005. EU Governments Agree Voluntary Code for Cross-Border Competition in Defense Equipment Markets. Brussels. European Defense Agency. (21 November 2005).

Hartley, K. 1995. "Industrial Policies in the Defense Sector," pp. 459-489 in Hartley, K. and T. Sandler, eds. Handbook of Defense Economics. Vol. 1. Amsterdam: North Holland.

Hartley, K. 2006. "Defense Industrial Policy in a Military Alliance.” Journal of Peace Research Vol. 43, pp. 473-489.

Hartley, K. 2007. "The Economics of the UK Defense Industrial Strategy." Security Challenges Vol. 3, No. 2, pp. 19-30.

Hartley, K., and T. Sandler. 2003. "The Future of the Defense Firm.” Kyklos Vol. 56, pp 361-380.

Ireland, G. 2007. "Beyond Artful: Government and Industry Roles in Britain's Future Submarine Design, Build and Support." Whitehall Report, 3-07. London: Royal United Services Institute.

Kuechle, H. 2006. "The Cost of Non-Europe in the Area of Security and Defense." Brussels: European Parliament. (June).

[NAO] National Audit Office. 2001. "Maximising the Benefits of Defence Equipment Co-operation." London: National Audit Office. HC 300 (March).

Sköns, E. and Surrey, E. 2005. “The Expanding Military Services Industry,” pp. 389393 in SIPRI Yearbook 2005. Oxford; Oxford University Press.

[USDC]. United States Department of Commerce. 2007. "Offsets in Defense Trade: Eleventh Report to Congress." Bureau of Industry and Security. Washington, DC: U.S. Department of Commerce. (January). 